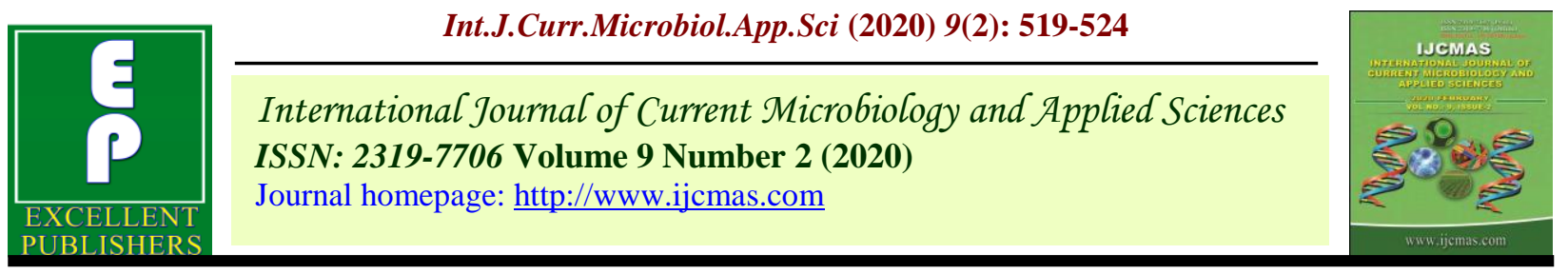

Original Research Article

https://doi.org/10.20546/ijcmas.2020.902.064

\title{
Effect of Different Plant Growth Hormones on Morpho-Physiological and Yield attributing Characteristics in Kalmegh (Andrographis paniculata Burn F. Ex)
}

\author{
D. K. Raidas ${ }^{1 *}$, S. D. Upadhayaya ${ }^{2}$ and A. Sharma ${ }^{3}$ \\ ${ }^{1}$ Department of Plant Physiology, RAK College of Agriculture, Sehore 466001, Rajmata \\ Vijayaraje Scindia Krishi Vishwa Vidhyalya, Gwalior, Madhya Pradesh 474002, India \\ ${ }^{2}$ Department of Plant Physiology, College of Agriculture, Jabalpur, Jawaharlal Nehru Krishi \\ Vishwa Vidhyalya, Jabalpur-482004, Madhya Pradesh, India \\ ${ }^{3}$ Department of Biological Science, Rani Durgawati Vishwa Vidhyalya, Jabalpur Madhya \\ Pradesh 474002, India \\ *Corresponding author
}

\begin{tabular}{|c|}
\hline Keywords \\
\hline $\begin{array}{l}\text { Cycocel, GA, NAA } \\
\text { spray, ppm, Leaf } \\
\text { area, Chlorophyll } \\
\text { content, } \\
\text { Andrographolide }\end{array}$ \\
\hline Article Info \\
\hline $\begin{array}{l}\text { Accepted: } \\
\text { 08 January } 2020 \\
\text { Available Online: } \\
\text { 10 February } 2020\end{array}$ \\
\hline
\end{tabular}

Keywords

Cycocel, $\mathrm{GA}_{3}$, NAA spray, ppm, Leaf area, Chlorophyll content,

pholide

rticle Info

Accepted:

Available Online:

10 February 2020

\section{A B S T R A C T}

Andrographis paniculata, commonly known as Kalmegh, is used both in Ayurvedic and Unani system of medicines because of its immunological, antibacterial and hepatoprotective properties. It is an annual herb has high value compound used in the treatment of the various diseases. A field experiment was conducted at the research farm of RAK College of Agriculture, Sehore (Madhya Pradesh) during Kharif 2015 \& 2016. Investigations undertaken aiming to increase the growth and yield parameters of Kalmegh. Using different Plant Growth Hormones Cycocel (100, 150 and 200 ppm), GA 3 (100, 150 and $200 \mathrm{ppm}$ ) and NAA (100 and $150 \mathrm{ppm}$ ) and water spray as control to study the effect of plant growth Hormones on Growth viz plant height $(\mathrm{cm})$, leaf area $\left(\mathrm{cm}^{2}\right)$, chlorophyll content, photosynthesis rate $\left(\mu \mathrm{mol} \mathrm{CO} \mathrm{Cm}^{-2} \mathrm{~s}^{-1}\right)$ at $90 \mathrm{DAS}$ and yield viz test weight $(\mathrm{g})$, seed yield $\left(\mathrm{kg} \mathrm{ha}^{-1}\right)$, herbage yield $\left(\mathrm{q} \mathrm{ha}^{-1}\right)$ and leaf alkaloid content $(\%)$ of kalmegh at harvesting. Foliar spray of GA 3 @150 ppm, GA 3100 ppm, cycocel@100ppm and GA 3 $100 \mathrm{ppm}$ significantly maximum the plant height (47.33), leaf area (420.82), chlorophyll content (57.78) photosynthesis rate (24.78) during 2015-16 and spray with $\mathrm{GA}_{3} @ 100$ ppm, applies the maximum plant height (46.20) and leaf area (426.41) was significantly differed from other treatments during 2016-17. Significantly higher seed yield (521.03, 531.17), herbage yield (185.50 193.23) and leaf andrographolide alkaloid content (2.89, 3.02) was observed by treatment $\mathrm{GA}_{3} @ 100$ ppm during both the year respectively.

\section{Introduction}

Kalmegh (Andrographis paniculata Burn F. Ex) important medicinal plant belonging to the family Acanthaceae. Which is indigenous to India and has been used in Indian systems of medicines since time immemorial. The plant is also known as Rice bitters in West 
Indies and king of bitters or Chiretta in England. It is an erect or recumbent, annual herbaceous plant. The branches are quadrangular, leaves simple petiolate, lanceolate with acute base and apex. Flowers are small, solitary and panicles with externally hairy rose or purple colored corolla, calyx-lobes glandular, pubescent, anther bearded at the base, fruits $20 \mathrm{~mm}$ long linear - oblong capsules acute at both ends. Seeds are numerous (i.e. containing 8-12 seeds per plant) yellowish brown. The leaves of Kalmegh contain maximum active principle Andrographolides, HomoAndrographolides, Andrographesterol and Andrographone. Andrographolides the major constituent in leaves which is bitter substance. The leaves contain much more of Andrographolides then seed. The average Andrographolides content varied from 12.44 to $33.52 \mathrm{mg} / \mathrm{g}$ in dried leaves which is found maximum at 90-120 days. Whole part of the plant like leaves, stem and roots are used in different medicine. Four lactones, viz. deoxyandrographolide, andrographolide, neo andrographolide and deoxy didehydro andrographolide were found in Andrographis paniculata (Sangalungkarn et al., 1990). Kalmegh is used in 26 Ayurvedic formulations as evidenced from Indian Pharmacopoeia; while, in Chinese Medicine it is an important "cold property" herb and is used to release body heat in fever, and prevent common cold. This is also possesses anti diabetes, anti-jaundice, anti-inflammatory anti-ulcer genic, anti-typhoid, anti HIV, and antimalarial, antifertility, anticancer, and antiviral properties. (Joseph and Solomon, 2014). In kalmegh major economic part of the plant is leaves. Growth regulators directly influence on the vegetative growth of the plant. Foliar application of the growth regulators directly enter plant and it help to increase the growth and yield of the kalmegh. So to know the potential of the plant hormones like Cycocel, $\mathrm{GA}_{3}$ and NAA the present study was undertaken with the objective to maximize growth and yield of kalmegh. It also helped to find out the different concentration of the plant hormone which increase the yield. Further, study was taken for higher production at lower cost.

\section{Materials and Methods}

This study was conducted at A field experiment was carried out in the research farm of RAK College of Agriculture, Sehore (Madhya Pradesh) during Kharif (2015 and 2016). There were eight treatments Cycocyl @ 100, 150 and 200 ppm, GA 3 @ 100, 150 and 200 ppm and NAA@100 and 150 ppm and the water being the control. This study was done on the base of randomized complete block design. The treatment was replicated 3 times. The plant growth regulators were sprayed in three stages viz seedling stage, vegetative stages and reproductive stage. The local kalmegh variety seeds were sown in main field at $30 \times 15 \mathrm{~cm}$ spacing. The whole plot was divided into 3 block each representing the replication. Each block was then divided into unit plot of $2 \times 3 \mathrm{~m}$ size. The experiment plot fertilized with urea, single super phosphate and murate of potash @ of NPK $75 \mathrm{~kg}, 75 \mathrm{~kg}$ and $50 \mathrm{~kg} \mathrm{ha}^{-1}$ respectively. All the operations done regularly during growing season. The growth and yield parameter observations were recorded at 90 DAS and harvesting on five randomly selected plants from every treatment. The collected data includes plant height, Leaf area will be determined by leaf area meter with conveyer attachment, chlorophyll content will be determined by using Minolata SPAD 502 plus Chlorophyll. The instrument measuring the relative amount of chlorophyll present in plant leaves in unit of SPAD (Soil Plant Analysis Development). Photosynthesis rate using IRGA (Licor instruments, USA as per method), test weight, seed yield, herbage yield and leaf andrographolide content will be 
estimated by HPTLC method. Finally mean data of the all characters were computed for statistical analysis as per standard procedure given by (Panse and Sukhtme 1989).

\section{Results and Discussion}

\section{Morpho-physiological characteristics}

\section{Plant height (cm)}

The data on plant height per plant $(\mathrm{cm})$ at 90 days as influenced by different plant growth hormones at harvesting was recorded during both the years and pooled data are presented in (Table -1). The effect of different concentration of plant growth hormones was significant of crop on plant height on both the year and pooled analysis. The average plant height was higher during 2015 (39.57) than 2016 (39.41). The maximum plant height significantly during 2015 found was spray with $\mathrm{GA}_{3} @ 150 \mathrm{ppm}$ (47.33) and it was at par with all other treatments due to apply with $\mathrm{GA}_{3}$ induces cell division, cell elongation, cell expansion, auxin metabolism, increase membrane permeability, photosynthesis, flowering in plants, stimulating rapid stem growth. Closely followed by spray with NAA @ 100ppm (44.68), GA3 @ 200ppm (44.63) and GA3 @ 100ppm (43.93) as compare to control (34.74) respectively. Similar results reported on the medicinal plant (Gloriosa Superba L.) by K. Kannabiran and Padmanaban (2016). During 2016 significantly maximum plant height was recorded spray with GA3 @100 ppm (48.47) which was at par with all the treatments except spray with Cycocel @200ppm (31.19).

\section{Leaf area $\left(\mathrm{cm}^{2}\right)$}

The data on leaf area per plant at 90 days was recorded during both the years and pooled data are presented in (Table -1). The effect of different concentration of plant growth hormones was significantly at 90 days of crop on leaf area $\left(\mathrm{cm}^{2}\right)$ per plant in both the year and pooled analysis. The average leaf area per plant was higher during 2016 (391.23) than 2015 (388.31). The maximum leaf area significantly during 2015 found was spray with GA3 100ppm (420.82). and it was at par with all other treatments. Closely followed by spray with GA3 @ 150ppm (415.89), GA 3 @ 200ppm (414.60) and NAA @ 100ppm (410.64) as compare to control (351.78) respectively. While, leaf area $\left(\mathrm{cm}^{2}\right)$ was minimum (354.03) treated with Cycocel @ 200ppm respectively. During 2016-17 significantly maximum plant height was recorded spray with $\mathrm{GA}_{3} @ 100$ ppm (426.41) which was at par with all the treatments. Closely followed by spray with $\mathrm{GA}_{3} @$ 150ppm (422.86), NAA @ 100ppm (413.30) and $\mathrm{GA}_{3} @$ 200ppm (411.13) as compare to control (353.50) respectively. While, leaf area $\left(\mathrm{cm}^{2}\right)$ was minimum (358.14) treated with spray with Cycocel @ 100ppm (358.14). Exogenous application of $\mathrm{GA}_{3}$ evokes the intrinsic genetic potential of the plant to cause increased cell division and cell wall extensibility, thereby resulting in higher leaf area. Similar observations have been made by Srivastava and Srivastava (2007) in medicinal plant of Catharanthus roseus.

\section{Chlorophyll content (SPAD)}

The data on Chlorophyll content was recorded during both the years and pooled data are presented in (Table -1). The impact of different concentration of plant growth hormones was non significant at 90 days of crop during both the years and pooled analysis. It was observed that there was a continuous increase in the chlorophyll content at vegetative to reproductive stages of crop growth. The average Chlorophyll content was higher during 2015 (51.01) than 201617(46.71). The maximum chlorophyll content during 2015 found was spray with cycocel 100ppm (57.78) and it was at par with all other treatments. Closely followed by spray 
with cycocel @ 200ppm (55.59), cycocel @ 150ppm (54.26) and NAA @ 100ppm (53.72) respectively. While, chlorophyll content was minimum (45.62) treated with NAA @ $150 \mathrm{ppm}$ as compare to control (41.78) respectively. The maximum chlorophyll content during 2016 found was spray with $\mathrm{GA}_{3}$ 150ppm (49.35) and it was at par with all other treatments. The minimum chlorophyll was noted treated with $\mathrm{GA}_{3}$ @200ppm (42.68) as compare to control (43.19) respectively.

\section{Yield attributing characteristics}

\section{Seed yield $\left(\mathrm{kg} \mathrm{ha}^{-1}\right)$}

The data on seed yield as influenced by different plant growth hormones at harvesting was recorded during both the years and pooled data are presented in (Table -2). The impact of different concentration of plant growth hormones was significant of crop on seed yield in both the year and pooled analysis. The average seed yield was higher during 2016 (454.48) than 2015 (441.77). The maximum seed yield significantly both the year and pooled found was spray with $\mathrm{GA}_{3}$ @ 100ppm (521.03, 531.17, 526.10) and it was at par with all other treatments. Closely followed by spray with cycocel @ 100ppm (495.87), NAA @ 100ppm (479.00) and NAA @ 150ppm (454.25) as compare to control (372.41) during 2015 and during 2016. Closely followed by spray with cycocel @ 100ppm (513.47), NAA@100ppm (482.59) and NAA@150ppm (477.12) as compare to control (382.35) respectively.

\section{Herbage yield (q ha $\left.{ }^{-1}\right)$}

The data on herbage yield as influenced by different plant growth hormones at harvesting was recorded during both the years and pooled data are presented in (Table -2). The impact of different concentration of plant growth hormones was significant of crop on herbage yield in both the year and pooled analysis. The average herbage yield was higher during 2015 (187.59) than 2016 (168.95). The maximum herbage yield significantly both the year and pooled found was spray with $\mathrm{GA}_{3}$ 100ppm $(185.51,193.23$, 189.37) and it was at par with all other treatments. Similarly results have been (Andrographis paniculata Nees.) recorded by Sowmya Kumari and Umesha K (2018). Closely followed by spray with NAA @ 100ppm (176.28), GA $@$ @ 150ppm (174.66) and Cycocel @ 100ppm (160.75) as compare to control (150.82) during 2015-16.The increase in the herbage yield mainly due to the fact that the growth regulators increase the number of leaves production which results in the production and accumulation of more photosynthates. and during 2016. Closely followed by spray with cycocel @ 100ppm (180.24), NAA@ 100ppm (168.52) and NAA@150ppm (166.74) as compare to control (159.30) respectively.

\section{Leaf alkaloid content (\% w/w)}

The data on leaf alkaloid content as influenced by different plant growth hormones at harvesting was recorded during both the years and pooled data are presented in (Table -2). The impact of different concentration of plant growth hormones was significant of crop on leaf alkaloid content in both the year and pooled analysis. The average leaf alkaloid content was higher during 2016 (2.40) than 2015 (2.41). The maximum leaf alkaloid content significantly both the year and pooled found was spray with $\mathrm{GA}_{3} 100 \mathrm{ppm}(2.89,3.02,2.96)$ and it was at par with all other treatments. Similar results have been registered by Menaria and Maliwal (2006) in fennel. The minimum leaf alkaloid content both the year and pooled found was treated with cycocel @ 200ppm $(2.03,1.86 .1 .94)$ as compare to control $(1.36,1.72,1.54)$ respectively. 
Table.1 Effect of different plant growth hormones on morpho-physiological characteristics in Kalmegh (Andrographis paniculata Burn F. Ex)

\begin{tabular}{|c|c|c|c|c|c|c|c|c|c|}
\hline \multirow[t]{2}{*}{ Treatments } & \multicolumn{3}{|c|}{$\begin{array}{l}\text { Plant height }(\mathrm{cm}) \\
\text { (90 Days) }\end{array}$} & \multicolumn{3}{|c|}{$\begin{array}{c}\text { Leaf area }\left(\mathrm{cm}^{2} \text { Plant }^{-1}\right) \\
(90 \text { Days })\end{array}$} & \multicolumn{3}{|c|}{$\begin{array}{c}\text { Chlorophyll content } \\
\text { (SPAD) } \\
90 \text { Days }\end{array}$} \\
\hline & 2015 & 2016 & Pooled & 2015 & 2016 & Pooled & 2015 & 2016 & Pooled \\
\hline $\begin{array}{l}\text { Cycocel @100 } \\
\text { ppm }\end{array}$ & 33.30 & 35.99 & 34.64 & 367.82 & 358.14 & 362.98 & 57.78 & 46.14 & 51.96 \\
\hline $\begin{array}{l}\text { Cycoce@I } 150 \\
\text { ppm }\end{array}$ & 33.42 & 35.68 & 34.55 & 360.73 & 372.58 & 366.65 & 54.26 & 48.22 & 51.24 \\
\hline $\begin{array}{l}\text { Cycocel @200 } \\
\text { ppm }\end{array}$ & 32.92 & 31.19 & 32.05 & 354.03 & 364.01 & 359.02 & 55.59 & 48.93 & 52.26 \\
\hline GA 3 @100 ppm & 43.93 & 48.47 & 46.20 & 420.82 & 426.41 & 423.61 & 50.8 & 48.15 & 49.47 \\
\hline $\mathbf{G A}_{3 @ 150} 15 p m$ & 47.33 & 42.32 & 44.82 & 415.89 & 422.86 & 419.37 & 52.45 & 49.35 & 50.90 \\
\hline GA3 @200 ppm & 44.63 & 41.83 & 43.23 & 414.60 & 411.13 & 412.86 & 47.11 & 42.68 & 44.89 \\
\hline NAA @100 ppm & 44.68 & 43.30 & 43.99 & 410.64 & 413.30 & 411.97 & 53.72 & 49.13 & 51.42 \\
\hline NAA @150 ppm & 41.20 & 39.78 & 40.49 & 398.50 & 399.22 & 398.86 & 45.62 & 44.61 & 45.11 \\
\hline Control & 34.74 & 36.16 & 35.45 & 351.78 & 353.50 & 352.64 & 41.78 & 43.19 & 42.48 \\
\hline Mean & 39.57 & 39.41 & 39.49 & 388.31 & 391.23 & 389.77 & 51.01 & 46.71 & 48.85 \\
\hline $\mathrm{SE}(\mathrm{m}) \pm$ & 2.33 & 3.00 & 2.66 & 11.76 & 14.04 & 12.90 & 0.98 & 2.64 & 1.81 \\
\hline C D at $5 \%$ & 7.18 & 8.98 & 8.08 & 35.27 & 42.07 & 38.67 & NS & NS & NS \\
\hline
\end{tabular}

Table.2 Effect of different plant growth hormones on yield attributing characteristics at harvest in Kalmegh (Andrographis paniculata Burn F. Ex)

\begin{tabular}{|c|c|c|c|c|c|c|c|c|c|}
\hline \multirow[t]{2}{*}{ Treatments } & \multicolumn{3}{|c|}{ Seed yield $\left(\mathrm{kg} \mathrm{ha}^{-1}\right)$} & \multicolumn{3}{|c|}{ Herbage yield $\left(\mathrm{q} \mathrm{ha}^{-1}\right)$} & \multicolumn{3}{|c|}{$\begin{array}{l}\text { Leaf Alkaloid content } \\
\qquad(\% \mathrm{w} / \mathrm{w})\end{array}$} \\
\hline & 2015 & 2016 & Pooled & 2015 & 2016 & Pooled & 2015 & 2016 & Pooled \\
\hline $\begin{array}{l}\text { Cycocel @100 } \\
\text { ppm }\end{array}$ & 495.87 & 513.47 & 504.67 & 160.75 & 180.24 & 170.49 & 1.78 & 2.64 & 2.21 \\
\hline $\begin{array}{l}\text { Cycoce@1 } 150 \\
\text { ppm }\end{array}$ & 424.51 & 417.84 & 421.17 & 154.72 & 163.19 & 158.95 & 1.53 & 2.4 & 1.96 \\
\hline $\begin{array}{l}\text { Cycocel @200 } \\
\text { ppm }\end{array}$ & 407.04 & 416.29 & 411.66 & 151.62 & 162.03 & 156.82 & 1.31 & 1.89 & 1.60 \\
\hline $\mathbf{G A}_{3} @ 100$ ppm & 521.03 & 531.17 & 526.10 & 185.51 & 193.23 & 189.37 & 2.7 & 2.97 & 2.83 \\
\hline $\mathbf{G A}_{3 @ 150} 15 p m$ & 448.04 & 475.33 & 461.68 & 174.66 & 165.16 & 169.91 & 2.93 & 2.48 & 2.70 \\
\hline $\mathbf{G A}_{3} @ 200$ ppm & 373.84 & 394.18 & 384.01 & 155.94 & 162.15 & 159.04 & 2.85 & 2.66 & 2.75 \\
\hline NAA@100 ppm & 479.00 & 482.59 & 480.79 & 176.28 & 168.52 & 172.40 & 3.05 & 2.58 & 2.81 \\
\hline NAA@150 ppm & 454.25 & 477.12 & 465.68 & 156.46 & 166.74 & 161.60 & 2.11 & 2.4 & 2.25 \\
\hline Control & 372.41 & 382.35 & 377.38 & 150.82 & 159.3 & 155.06 & 1.28 & 1.72 & 1.50 \\
\hline Mean & 441.77 & 454.48 & 448.12 & 187.59 & 168.95 & 165.96 & 2.40 & 2.41 & 2.40 \\
\hline $\mathrm{SE}(\mathrm{m}) \pm$ & 13.89 & 14.12 & 14.00 & 5.74 & 5.21 & 5.47 & 0.26 & 0.21 & 0.23 \\
\hline C D at $5 \%$ & 41.65 & 32.02 & 36.83 & 17.2 & 16.10 & 16.65 & 0.79 & 0.64 & 0.71 \\
\hline
\end{tabular}


Conclusion of the study are as follows:

From the present investigation, it can be foliar spray of growth hormones on vegetative stages and reproductive stage after seeds sown of Kalmegh viz GA 3 @ 150ppm, GA 3 @ 100ppm and Cycocel @ 100ppm was most effective for realizing significantly maximum plant height leaf area, chlorophyll content and photosynthesis rate during 2015 and spray with $\mathrm{GA}_{3} @ 100$ ppm, the maximum plant height, leaf area, and photosynthesis rate was significantly differed from other treatments during 2016 to realize ultimately maximum profit correlated with herbage yield, alkaloid yield and seed yield of Kalmegh.

\section{Acknowledgments}

We are thankful to the Department of Plant Physiology, College of Agriculture, Jabalpur (JNKVV), Department of Bioscience, RDVV, Jabalpur (M.P.) and IISS, Bhopal for providing lab facilities for the analysis. And with thanks for the research farm College of Agriculture, Sehore (Madhya Pradesh) for conducted of experiments.

\section{References}

Joseph J, Solomon JJ. (2014). Andrographis paniculata: A Review of its Traditional Uses, Phytochemistry and Pharmacology. Med. Aromat. Plants. 2014; 3:1-15.

Kannabiran, K. and Padmanaban (2016).
Effect of Growth Regulators and Tuber Weight on Plant Height and Number of Branches in Glory Lily (Gloriosa superba L.). International Journal of Innovative Research and Development, ISSN 2278 pp 342

Menaria, B.L. and Maliwal P.L. (2006). Effect of plant density, level of fertilizer and growth regulators on yield attributes and yield of transplanted fennel (Foeniculum vulgare Mill.). Ind. J. Agri. Sci., 76(4): 235-237

Panse, V.G. and Sukhatme, P.V. (1989). Statical methods for Agriculture workers. ICAR New Delhi, pp. 97-105.

Sangalungkarn V, Thummauppakorn P, Kittiyanee U, Chaichantipyuth C. (1990). The effect of andrographolide, neoandrographolide and 14-deoxy 11, 12-dedehydro andrographolide on the intestinal motility of white rat. The J Pharm. Sci.15:5-7.

Sowmya Kumari and Umesha K. (2018). Influence of plant growth regulators on yield and economics of cultivation of Kalmegh (Andrographis paniculata Nees.) International Journal of Chemical Studies 2018; 6 (6): 13171319

Srivastava, N. K. and Srivastava, A. K., (2007). Influence of gibberellic acid on ${ }^{14} \mathrm{CO}_{2}$ metabolism, growth, and production of alkaloids in Catharanthus roseus. Photosynthetica, 45 (1):156-160.

\section{How to cite this article:}

Raidas, D. K., S. D. Upadhayaya and Sharma, A. 2020. Effect of Different Plant Growth Hormones on Morpho-Physiological and Yield attributing Characteristics in Kalmegh (Andrographis paniculata Burn F. Ex). Int.J.Curr.Microbiol.App.Sci. 9(02): 519-524. doi: https://doi.org/10.20546/ijcmas.2020.902.064 